\title{
PENGARUH PENGGUNAAN TEKNOLOGI INFORMASI DAN KOMUNIKASI SEBAGAI MEDIA PEMBELAJARAN TERHADAP PRESTASI BELAJAR SISWA DI MIN KEPATIHAN BOJONEGORO
}

\author{
Ahmad Manshur \\ Institut Agama Islam Sunan Giri Bojonegoro \\ Email: ahmanshur@gmail.com
}

\begin{abstract}
Pemanfaatan teknologi informasi dan komunikasi diharapkan mampu meningkatkan keberhasilan proses belajar mengajar. Memanfaatkan TIK dalam pelaksanaan pembelajaran karena tidak didukung dengan sarana prasarana yang memadai. Pembelajaran hanya monoton dilakukan di ruang kelas dan dengan ceramah sehingga siswa merasa jenuh. Berdasarkan uraian diatas maka permasalahan penelitian adalah (1) bagaimanakah efektivitas penggunaan teknologi informasi dan Komunikasi terhadap prestasi belajar siswa di MIN Kepatihan Bojonegoro. (2) bagaimanakah efektivitas media pembelajaran terhadap prestasi belajar siswa di MIN Kepatihan Bojonegoro. (3) bagaimanakah efektivitas penggunaan teknologi informasi dan komunikasi sebagai media pembelajaran terhadap prestasi belajar siswa di MIN Kepatihan Bojonegoro. Metode dalam penelitian ini explanatory survey, yaitu merupakan suatu jenis metode penelitian deskriptif yang dilakukan terhadap subyek dan obyek penelitian dalam jumlah besar dalam waktu yang bersamaan. Hasil perhitungan uji F (test anova) penggunaan teknologi informasi dan komunikasi sebagai media pembelajaran terhadap prestasi belajar siswa dapat dilihat pada Tabel Coefficient. Dari uji $F$ (test anova), didapat $F$ hitung adalah 15.518 dengan tingkat signifikansi 0,044. Karena probabilitas $(0,044)$ jauh lebih kecil dari 0,05 berarti $\mathrm{H}_{0}$ ditolak, yang berarti bahwa penggunaan teknologi informasi dan komunikasi sebagai media pembelajaran secara simultan berpengaruh terhadap prestasi belajar siswa.
\end{abstract}

Kata Kunci : Penggunaan Teknologi Informasi dan Komunikasi, Media Pembelajaran dan Prestasi Belajar Siswa

\section{Pendahuluan}

Pemanfaatan teknologi informasi dan komunikasi diharapkan mampu meningkatkan keberhasilan proses belajar mengajar. Dalam buku "Pembelajaran Jarak Jauh Berbasis Teknologi Informasi dan Komunikasi” mengatakan bahwa penerapan aplikasi teknologi informasi dan komunikasi yang tepat dalam dunia pendidikan merupakan salah satu faktor kunci penting untuk meningkatkan kualitas pendidikan dan kualitas sumber daya manusia. Penerapan dan pengembangan teknologi informasi dan komunikasi bukan sekedar mengikuti trend global melainkan merupakan suatu langkah strategis dalam upaya meningkatkan akses dan mutu pendidikan. Hal ini juga merupakan salah satu faktor kunci 
untuk mengejar ketertinggalan dunia pendidikan dan kualitas sumber daya manusia Indonesia dengan bangsa-bangsa lain. ${ }^{1}$

Ada banyak hal yang mampu mempengaruhi proses belajar. Salah satunya adalah motivasi. Adanya motivasi yang baik dalam belajar akan menunjukkan hasil yang baik. Dengan usaha yang tekun dan didasari adanya motivasi, maka seseorang yang belajar tersebut akan melahirkan prestasi yang baik. Intensitas motivasi seseorang akan menentukan tingkat pencapaian prestasi belajarnya (Sardiman, 2006: 85-86). Oleh karena itu untuk mewujudkan kualitas sumber daya manusia yang baik maka setidaknya peserta didik harus memiliki prestasi belajar yang baik. Prestasi belajar yang baik bisa diwujudkan salah satunya dengan meningkatkan motivasi belajar melalui pemanfaatan teknologi informasi dan komunikasi dalam proses pembelajaran.

Dari hasil pengamatan ke beberapa sekolah di Bojonegoro untuk tingkat MI beberapa sekolah sudah memiliki laboratorium komputer. Namun karena sumber daya manusia belum mendukung, kebanyakan mereka mendatangkan guru dari luar. Dari pengamatan tampak bahwa yang diajarkan terfokus pada pengajaran komputer dengan perangkat lunak tertentu, sedangkan TIK sendiri menurut kurikulum 2004 bukanlah komputer.

Visi mata pelajaran Teknologi Informasi dan Komunikasi menurut kurikulum TIK 2004 yaitu agar siswa dapat menggunakan perangkat Teknologi Informasi dan Komunikasi secara tepat dan optimal untuk mendapatkan dan memproses informasi dalam kegiatan belajar, bekerja, dan aktifitas lainnya sehingga siswa mampu berkreasi, mengembangkan sikap inisiatif, mengembangkan kemampuan eksplorasi mandiri, dan mudah beradaptasi dengan perkembangan yang baru. Berdasarkan visi kurikulum TIK adalah untuk menciptakan siswa yang mampu mengatur diri dalam belajarnya. ${ }^{2}$

Dalam pelajaran TIK sekolah umumnya menyediakan peralatan TIK yaitu komputer. Salah satu keunggulan komputer adalah dukungan multimedia didalamnya. Aplikasi Multimedia pembelajaran dapat menyajikan konsep dan keterampilan tingkat tinggi dalam pembelajaran, yang memiliki keterkaitan antara satu unsur dan unsur lainnya yang sulit diajarkan dan dipelajari melalui buku semata. Kelebihan aplikasi multimedia interaktif pembelajaran dalam menjelaskan suatu konsep dapat menuntut siswa untuk bereksplorasi dan menganalisis, mencoba dan menggali konsep dan prinsip yang termuat dalam suatu materi yang dihadapinya, sehingga dapat relatif lebih cepat membangun struktur pemahaman

\footnotetext{
${ }^{1}$ E. Mulyasa, Op Cit, hal. 34

${ }^{2}$ Budi Sutedjo Dharma Oetomo, e-Education Konsep, Teknologi, dan Aplikasi Internet Pendidikan, Yogyakarta, C.V. Andi Offset, 2007, hal. 44
} 
siswa, karena terintegrasinya komponen- komponen seperti suara, teks, animasi, gambar, dan video berfungsi untuk mengoptimalkan peran indera dalam menerima informasi ke dalam sistem memori. ${ }^{3}$

Dengan adanya kenyataan tersebut penulis ingin mengetahui apakah dalam penggunaan teknologi informasi dan komputer dalam proses pembelajaran itu mampu meningkatkan proses pembelajaran pendekatan scientific dari pada tidak menggunakan teknologi informasi dan komputer. Keadaan itu menuntut MIN Kepatihan Bojonegoro untuk menerapkan rencana strategisnya terutama dalam upaya peningkatan prestasi belajar siswanya. Untuk itulah maka penulis tertarik untuk menyusun tesis ini dengan judul "Pengaruh Penggunaan Teknologi Informasi dan Komunikasi sebagai Media Pembelajaran terhadap Prestasi Belajar Siswa di MIN Kepatihan Bojonegoro”.

\section{METODOLOGI PENELITIAN}

Penelitian ini menggunakan metode kuantitatif. Penelitian ini merupakan penelitian sampel. Dalam penelitian ini yang menjadi populasi adalah seluruh siswa MIN Kepatihan Bojonegoro dengan jumlah 309 siswa. Dalam penelitian ini penulis mengambil 10\% dari total populasi sebagai sampel sehingga 10\% dari 309 siswa adalah sebanyak 30 siswa sebagai sampel penelitian. Adapun teknik yang penulis gunakan dalam pengambilan sampel adalah dengan teknik random sampling. yaitu pemilihan sampel dengan memberikan kesempatan kepada seluruh populasi. Adapun random yang penulis gunakan adalah dengan cara undian.

\section{Hasil Analisis Deskriptif}

Deskripsi data media pembelajaran di MIN Kepatihan Bojonegoro meliputi pengklasifikasian skor subjek menjadi 5 (lima) tingkatan yaitu tingkatan sangat baik, baik, cukup baik, kurang baik, dan sangat tidak baik. Dari hasil analisis data didapatkan fakta bahwa sebagian besar responden telah menggunakan media pembelajaran pada tingkatan yang sangat baik. Secara ringkas, klasifikasi media pembelajaran dari 30 responden adalah sebagaimana terdapat pada Tabel 1 dibawah ini.

Tabel 1. Ringkasan Pengklasifikasian Skor Media Pembelajaran

\begin{tabular}{|l|c|c|c|}
\hline \multicolumn{1}{|c|}{ Klasifikasi } & Rentang Interval & Frekuensi & Persentase \\
\hline Sangat rendah & $0,0-1,0$ & 0 & $0 \%$ \\
\hline
\end{tabular}

\footnotetext{
${ }^{3}$ Budi Sutedjo Dharma Oetomo, Op Cit, hal. 45
} 


\begin{tabular}{|l|c|c|c|}
\hline Rendah & $1,1-2,0$ & 0 & $0 \%$ \\
\hline Cukup & $2,1-3,0$ & 4 & $10.0 \%$ \\
\hline Baik & $3,1-4,0$ & 12 & $23.3 \%$ \\
\hline Sangat baik & $4,1-5,0$ & 14 & $66.7 \%$ \\
\hline \multicolumn{2}{|r|}{ Jumlah } & 30 & $100.0 \%$ \\
\hline
\end{tabular}

Dari Tabel 1 di atas didapatkan gambar grafik media pembelajaran di MIN Kepatihan Bojonegoro berikut ini.

Gambar 2 Grafik Frekuensi Media Pembelajaran

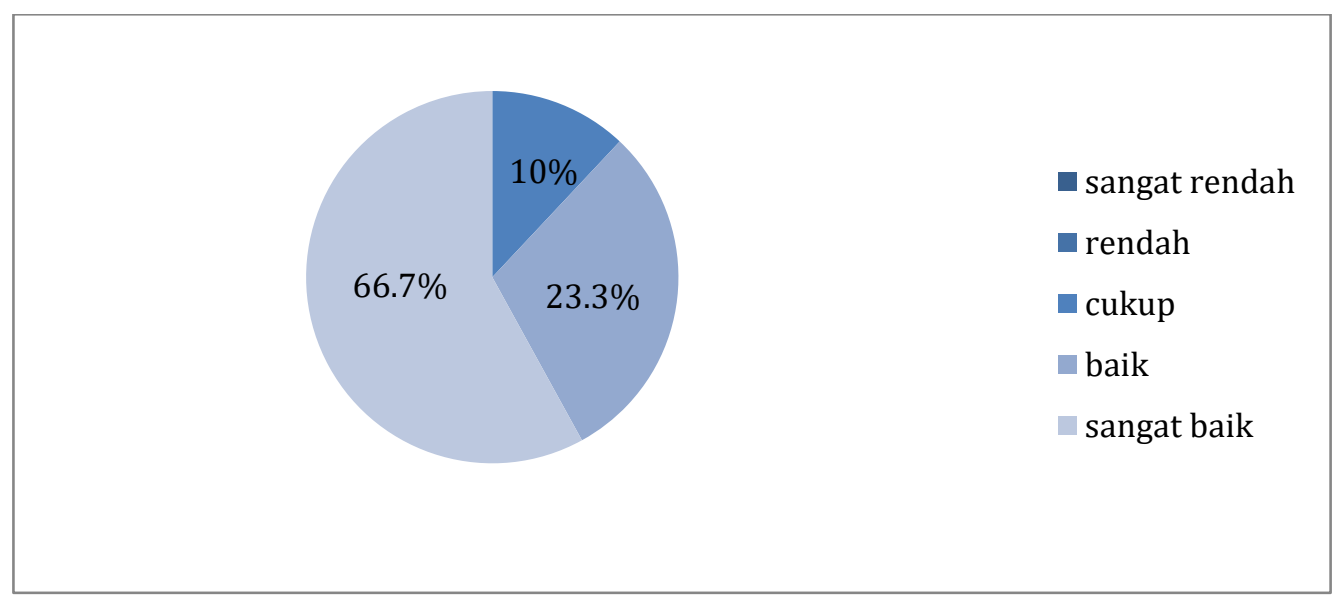

Berdasarkan Tabel dan Gambar 2 di atas pengklasifikasian skor media pembelajaran disimpulkan bahwa, secara umum guru MIN Kepatikan Bojonegoro sudah menggunakan media pembelajaran yang sangat baik. Hal ini disimpulkan dari 30 siswa, terdapat 14 siswa (66.7\%) menjawab media pembelajaran pada tingkat sangat baik, sebanyak 12 siswa (23.3\%) menjawab media pembelajaran pada tingkat baik, sebanyak 4 siswa (10.0\%) menjawab media pembelajaran pada tingkat cukup baik, serta tidak ada siswa yang menjawab media pembelajaran pada tingkat tidak baik dan sangat tidak baik.

\section{Uji Validitas}

\section{Media Pembelajaran}

Nilai koefisien korelasi untuk masing-masing item pertanyaan media pembelajaran yaitu $\mathrm{X}_{2} 1$ (tentang Metode mengajar yang digunakan guru saat ini sudah memadai) sebesar 0,604; X22 (tentang Guru perlu memperbaharui metode mengajarnya supaya tidak membosankan) sebesar 0,749; X23 (tentang Media pembelajaran yang ada saat ini cukup memadai) sebesar 0,330; X24 (tentang Guru perlu menggunakan media 
pembelajaran yang inovatif) sebesar 0,$625 ; X_{2} 5$ (tentang Guru perlu menyediakan bahan belajar untuk siswa yang bisa diakses / digunakan sewaktu-waktu di luar jam sekolah) sebesar 0,777; X26 (tentang TIK hendaknya sudah disediakan pihak sekolah) sebesar 0,516; X27 (tentang Pihak sekolah hendaknya menyediakan web based learning / e-learning sebagai pengayaan pembelajaran) 0,625; X28 (tentang Bahasan yang sulit dimengerti di kelas, di sediakan bahan lain dalam format multi media interaktif) sebesar 0,777; $\mathrm{X}_{2} 9$ (tentang Guru mengembangkan bahan ajar berbasis teknologi informasi dan komunikasi) sebesar 0,394; $\mathrm{X}_{2} 10$ (tentang Siswa menggunakan fasilitas teknologi informasi dan komunikasi di sekolah dan di rumah) sebesar 0,579;. Item pertanyaan media pembelajaran adalah valid karena memiliki nilai koefisien korelasi $\geq 0,3$.

\section{Uji Reliabilitas}

Hasil perhitungan uji reliabilitas menunjukkan nilai Cronbach's of Alpha penggunaan teknologi informasi sebesar 0,861; komunikasi sebagai Media pembelajaran sebesar 0,808; dan Prestasi Belajar siswa sebesar 0,867. Nilai Cronbach's of Alpha ketiga variabel yang diteliti lebih besar dari 0,7 maka kuesioner variabel penelitian dalam penelitian ini adalah reliabel.

\section{Uji Prasyarat}

\section{Uji Normalitas Data}

Berikut ini adalah grafik normal probability plot yang merupakan hasil output dari perhitungan yang dilakukan dalam penelitian ini.

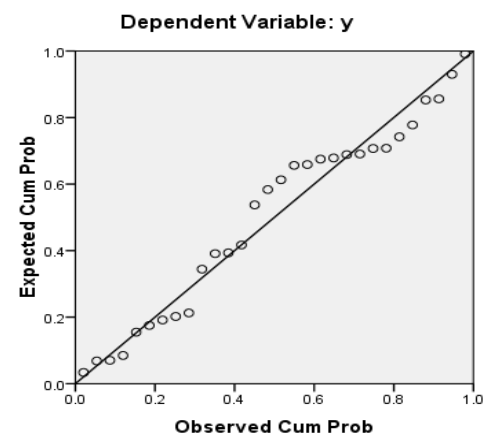


Dari grafik di atas menunjukkan bahwa data ada di sekitar garis diagonal dan mengikuti arah garis diagonal, maka data tersebut memenuhi asumsi normalitas, maka dapat disimpulkan bahwa data ketiga variabel dalam penelitian ini berdistribusi normal.

\section{Uji Heterokesdatisitas}

Berikut ini adalah grafik scatterplot yang menunjukkan hasil uji heteroskesdatisitas dalam penelitian ini.

Gambar 5. Grafik Uji Heteroskesdatisitas

Scatterplot

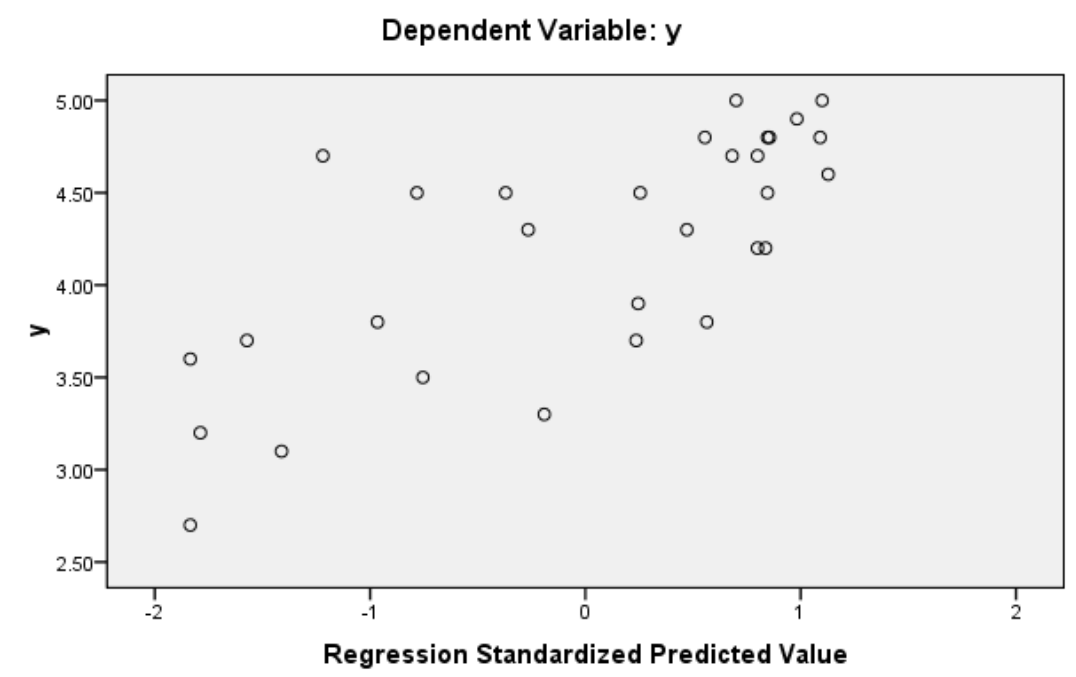

Berdasarkan gambar di atas hasil uji heteroskesdatisitas, terlihat titik-titik terpencar di atas maupun disumbu Y dan tidak membentuk sebuah pola tertentu. Hal ini berarti tidak terjadi heteroskesdatisitas pada penelitian ini, sehingga layak dipakai untuk memprediksi Prestasi Belajar siswa berdasarkan masukan variabel penggunaan teknologi informasi dan komunikasi sebagai media pembelajaran.

\section{Uji Analisis Regressi Berganda}

Analisis regresi digunakan untuk mengetahui besarnya pengaruh variabel bebas yaitu penggunaan teknologi informasi dan komunikasi sebagai media pembelajaran terhadap variabel terikat yaitu Prestasi Belajar siswa di MIN Kepatihan Bojonegoro. Analisis yang diteliti memberikan hasil seperti pada Tabel 4.8 berikut. 
Tabel 6. Hasil Analisis Regresi Berganda Efektivitas Penggunaan Teknologi Informasi dan Komunikasi sebagai Media Pembelajaran Terhadap Prestasi Belajar Siswa

Coefficients $^{a}$

\begin{tabular}{|c|c|c|c|c|c|c|}
\hline \multirow{2}{*}{\multicolumn{2}{|c|}{ Model }} & \multicolumn{2}{|c|}{ Unstandardized Coefficients } & \multirow{2}{*}{$\begin{array}{c}\begin{array}{c}\text { Standardized } \\
\text { Coefficients }\end{array} \\
\text { Beta }\end{array}$} & \multirow[b]{2}{*}{$\mathrm{t}$} & \multirow[b]{2}{*}{ Sig. } \\
\hline & & B & Std. Error & & & \\
\hline \multirow[t]{3}{*}{1} & (Constant) & 1.369 & .573 & & 2.389 & .024 \\
\hline & $x 1$ & .043 & .168 & .045 & .255 & .800 \\
\hline & $x 2$ & .628 & .157 & .701 & 3.990 & .000 \\
\hline
\end{tabular}

a. Dependent Variable: y

$\mid \begin{array}{ll}\mathrm{R} & =0.731 \\ \mathrm{R}^{2} & =0.535 \\ \mathrm{~F}_{\text {hitung }} & =15.518 \\ \text { Sig F } & =0,000\end{array}$

Berdasarkan Tabel 6 di atas dapat dibuat persamaan regresi berganda sebagai berikut:

$Y=1.369+0.043 X_{1}+6.28$

Persamaan tersebut menunjukkan:

1. Konstanta $(\mathrm{a})=1.369$; menyatakan bahwa jika $\mathrm{X}_{1}$ (penggunaan teknologi informasi dan komunikasi), dan $\mathrm{X}_{2}$ (media pembelajaran) konstan, maka prestasi belajar siswa akan meningkat sebesar $13.69 \%$.

2. Koefisien regresi $X_{1}$ sebesar 0.043 menunjukkan jika penggunaan teknologi informasi dan komunikasi mengalami kenaikan sebesar satu persen (1\%) sedangkan variabel yang lain $\mathrm{X}_{2}$ (media pembelajaran) konstan, maka prestasi belajar siswa akan meningkat sebesar $4.3 \%$.

3. Koefisien regresi $\mathrm{X}_{2}$ sebesar .628 menunjukkan jika media pembelajaran mengalami kenaikan sebesar satu persen (1\%) sedangkan variabel yang lain $\mathrm{X}_{1}$ (penggunaan teknologi informasi dan komunikasi) konstan, maka prestasi belajar siswa akan meningkat sebesar $62.8 \%$. 


\section{Uji Hipotesis}

\section{Uji t (t-test)}

Uji t digunakan untuk menguji tingkat signifikansi pengaruh masing-masing (parsial) variabel bebas $\left(\mathrm{X}_{1}\right.$ dan $\left.\mathrm{X}_{2}\right)$ yaitu penggunaan teknologi informasi dan komunikasi sebagai media pembelajaran terhadap variabel terikat (Y) yaitu prestasi belajar siswa.

Berdasarkan Tabel Coefficient di atas maka keputusan penerimaan atau penolakan hipotesis $\left(\mathrm{H}_{0}\right.$ dan $\left.\mathrm{H}_{1}\right)$ penggunaan teknologi informasi dan komunikasi sebagai media terhadap prestasi belajar siswa adalah sebagai berikut:

a. Pengaruh Variabel Penggunaan teknologi informasi dan komunikasi terhadap prestasi belajar siswa.

Variabel penggunaan teknologi informasi dan komunikasi mempunyai angka signifikansi 0.800 , yang berarti lebih besar dari nilai probabilitas $5 \%(\mathrm{p}=0,05)$. Dengan demikian maka $\mathrm{H}_{0}$ diterima dan $\mathrm{H}_{1}$ ditolak. Ini berarti bahwa variabel penggunaan teknologi informasi dan komunikasi $\left(\mathrm{X}_{1}\right)$ secara parsial tidak berpengaruh signifikan terhadap prestasi belajar siswa.

b. Pengaruh Variabel media pembelajaran terhadap prestasi belajar siswa.

Variabel media pembelajaran mempunyai angka signifikansi 0,444, yang berarti lebih kecil dari nilai probabilitas 5\% $(\mathrm{p}=0,05)$. Dengan demikian maka $\mathrm{H}_{0}$ ditolak dan $\mathrm{H}_{1}$ diterima. Ini berarti bahwa variabel komunikasi sebagai media pembelajaran $\left(\mathrm{X}_{2}\right)$ secara parsial berpengaruh signifikan terhadap pembelajaran dalam pendekatan experiment.

\section{Uji F (Uji Pengaruh Simultan)}

Uji $\mathrm{F}$ digunakan untuk menguji hipotesis $\left(\mathrm{H}_{1}\right)$ yaitu bahwa variabel bebas (penggunaan teknologi informasi dan komunikasi sebagai media pembelajaran) secara simultan berpengaruh signifikan terhadap variabel terikat (prestasi belajar siswa).

Hasil perhitungan uji $\mathrm{F}$ (test anova) penggunaan teknologi informasi dan komunikasi sebagai media pembelajaran terhadap prestasi belajar siswa dapat dilihat pada Tabel Coefficient. Dari uji F (test anova), didapat F hitung adalah 15.518 dengan tingkat signifikansi 0,000. Karena probabilitas $(0,000)$ jauh lebih kecil dari 0,05 berarti $\mathrm{H}_{0}$ ditolak, yang berarti bahwa penggunaan teknologi informasi dan komunikasi sebagai media pembelajaran secara simultan berpengaruh terhadap prestasi belajar siswa. 
Analisis model summary angka $\mathrm{R}$ sebesar 0,731 menunjukkan bahwa korelasi atau hubungan antara prestasi belajar siswa dengan variabel independennya adalah kuat. Definisi "kuat" karena angka di atas 0,5. Angka $\mathrm{R}^{2}$ atau Koefisien Determinasi adalah 0,535 (berasal dari 0,731 x 0,731). Hal ini berarti 53.5\% variasi dari prestasi belajar bisa dijelaskan oleh variasi dari variabel independen sedangkan sisanya (100\% $-53.5 \%$ $=46.5 \%$ ) dijelaskan oleh variabel-variabel lain di luar model penelitian ini.

\section{PEMBAHASAN HASIL PENELITIAN}

Berdasarkan koefisien regresi $\mathrm{X}_{1}$ sebesar 0.043 menunjukkan jika penggunaan teknologi informasi dan komunikasi mengalami kenaikan sebesar satu persen (1\%) sedangkan variabel yang lain $\mathrm{X}_{2}$ (media pembelajaran) konstan, maka prestasi belajar siswa akan meningkat sebesar $4.3 \%$.

Sesuai dengan hasil penelitian dan pengolahan data yang dilakukan, diperoleh besarnya penggunaan teknologi informasi dan komunikasi mempunyai angka signifikansi 0.800, yang berarti lebih besar dari nilai probabilitas $5 \%(\mathrm{p}=0,05)$. Dengan demikian maka $\mathrm{H}_{0}$ diterima dan $\mathrm{H}_{1}$ ditolak. Ini berarti bahwa variabel penggunaan teknologi informasi dan komunikasi $\left(\mathrm{X}_{1}\right)$ secara parsial tidak berpengaruh signifikan terhadap prestasi belajar siswa.

Berdasarkan koefisien regresi $\mathrm{X}_{2}$ sebesar .628 menunjukkan jika media pembelajaran mengalami kenaikan sebesar satu persen (1\%) sedangkan variabel yang lain $\mathrm{X}_{1}$ (penggunaan teknologi informasi) konstan, maka prestasi belajar siswa akan meningkat sebesar $62.8 \%$.

Sesuai dengan hasil penelitian dan pengolahan data yang dilakukan, diperoleh besarnya komunikasi sebagai media pembelajaran mempunyai angka signifikansi 0,444, yang berarti lebih kecil dari nilai probabilitas 5\% ( $\mathrm{p}=0,05)$. Dengan demikian maka $\mathrm{H}_{0}$ ditolak dan $\mathrm{H}_{1}$ diterima. Ini berarti bahwa variabel media pembelajaran $\left(\mathrm{X}_{2}\right)$ secara parsial berpengaruh signifikan terhadap prestais belajar siswa.

Berdasarkan konstanta $(\mathrm{a})=1.369$; menyatakan bahwa jika $\mathrm{X}_{1}$ (penggunaan teknologi informasi dan komunikasi), dan $\mathrm{X}_{2}$ (media pembelajaran) konstan, maka prestasi belajar siswa akan meningkat sebesar $13.69 \%$.

Hasil perhitungan uji F (test anova) penggunaan teknologi informasi dan komunikasi sebagai media pembelajaran terhadap prestasi belajar siswa dapat dilihat pada Tabel Coefficient. Dari uji F (test anova), didapat F hitung adalah 15.518 dengan tingkat signifikansi 0,444. Karena probabilitas $(0,444)$ jauh lebih kecil dari 0,05 berarti $\mathrm{H}_{0}$ ditolak, yang berarti bahwa penggunaan teknologi informasi dan komunikasi sebagai media pembelajaran secara simultan berpengaruh terhadap prestasi belajar siswa. 
Analisis model summary angka $\mathrm{R}$ sebesar 0,731 menunjukkan bahwa korelasi atau hubungan antara prestasi belajar siswa dengan variabel independennya adalah kuat. Definisi "kuat" karena angka di atas 0,5. Angka $\mathrm{R}^{2}$ atau Koefisien Determinasi adalah 0,535 (berasal dari $0,731 \times$ x 0,731$)$. Hal ini berarti $53.5 \%$ variasi dari prestasi belajar siswa bisa dijelaskan oleh variasi dari variabel independen sedangkan sisanya $(100 \%-53.5 \%=46.5 \%)$ dijelaskan oleh variabel-variabel lain di luar model penelitian ini.

\section{KESIMPULAN}

Efektivitas penggunaan teknologi informasi dan komunikasi sebagai media pembelajaran terhadap prestasi belajar siswa di MIN Kepatihan Bojonegoro. Berdasarkan hasil perhitungan uji $\mathrm{F}$ (test anova) penggunaan teknologi informasi dan komunikasi sebagai media pembelajaran teradap prestasi belajar siswa dapat dilihat pada Tabel Coefficient. Dari uji F (test anova), didapat $\mathrm{F}$ hitung adalah 15.518 dengan tingkat signifikansi 0,444 . Karena probabilitas $(0,444)$ jauh lebih kecil dari 0,05 berarti $\mathrm{H}_{0}$ ditolak, yang berarti bahwa penggunaan teknologi informasi dan komunikasi sebagai media pembelajaran secara simultan berpengaruh terhadap prestasi belajar siswa.

\section{DAFTAR PUSTAKA}

Ahmadi, Abu, Strategi Belajar Mengajar, Bandung, Pustaka Setia, 1997

Arikunto, Suharsimi, Prosedur Penelitian. Jakarta, Rineka Cipta, 2006

Asmani, Ma'mur, Jamal, Tips Efektif Pemanfaatan Teknologi Informasi dan Komunikasi Dalam Dunia Pendidikan, Jogjakarta, Diva Press, Jogjakarta, 2011

B. Uno, Hamzah \& Lamatenggo, Nina, Teknologi Komunikasi dan Informasi Pembelajaran, Jakarta, Bumi Aksara, 2011

Bahreisj, Hussein , Al-Jamius Shahih, Surabaya, Karya Utama, 1999

Darajad, Zakiah, Ilmu Pendidikan Islam, Jakarta, Bumi Aksara, 2002

Depag , Al-qur'an dan Terjemahnya, Semarang, Kumudasmoro Grafindo, 1994

Depag RI, Pedoman Pelakanaan Pendidikan Agama Pada SD, Jakarta, Depag RI, 1986

Depdikbud, Kamus Besar Bahasa Indonesia, Jakarta, Pustaka Setia, 1990

Departemen Agama, Undang-Undang dan Peraturan Pemerintah RI tentang Pendidikan, Jakarta, Dirjen Pendidikan Islam, 2006 
Dimyati dan Mudjiono, Belajar dan Pembelajaran, Jakarta, PT. Rineka Cipta, 2006

Djamaludin dan Abdullah Aly, Pendidikan Islam, Jakarta, Pustaka Setia, 1999

E. Mulyasa, 2008, Kurikulum Berbasis Kompetensi Konsep, Karakteristik, Implementasi dan Inovasi, Bandung, PT. Remaja Rosdakarya, 2008

MPR, Ketentuan Sidang Umum MPR. RI, Jakarta, Cicoroto,1988

Mardalis, Metode Penelitian Suatu Pendekatan Proposal, Jakarta, Bumi Aksara, 2007

Margono, S, Metodologi Penelitian Pendidikan, Jakarta, Rineka Cipta, 2007

Muhaimin, Paradigma Pendidikan Islam, Bandung, Remaja Rosdakarya, 2002

Oetomo, Dharma, Sutedjo, Budi, e-Education Konsep, Teknologi, dan Aplikasi Internet Pendidikan, Yogyakarta, C.V. Andi Offset, 2007

Peraturan Pemerintah Nomor 19 Tahun 2005 tentang Standar Nasional Pendidikan

Rusman, Model-Model Pembelajaran Mengembangkan Profesionalisme Guru, Jakarta, PT. RajaGrafindo Persada, , 2011

Santoso, Singgih, SPSS Versi 10 Mengolah Data Statistik Secara Profesional. Jakarta, PT. Elex Komputindo. 2001

Sekretaris Negara, Undang- undang Dasar, Jakarta, Cicoro, 1985

Shaleh, Abdul, Rahman, Pendidikan Agama dan Pembangunan Untuk Bangsa, Jakarta, PT. Raja Grafindo Persada, , 2005

Sugiyono, Statistika Penelitian. Bandung, CV. Alfabeta, 1999 , Metode Penelitian Administrasi, Bandung, Alfabeta, 2008

Tafsir, Ahmad, Pendidikan dalam Perspektif Islam, Bandung, Remaja Rosdakarya, 1992

Udin Saefudin Sa’ud, Saefudin, Udin, Inovasi Pendidikan, Bandung, AlfaBeta, 2008

Undang-Undang Nomor 20 Tahun 2003 tentang Sistem Pendidikan Nasional.

Warsita, Bambang, Teknologi Pembelajaran, Jakarta, PT. Rineka Cipta, 2008

Wena, Starategi Pembelajaran Inovatif Kontemporer; Suatu Tinjauan Konseptual Operasional, Jakarta, PT. Bumi Aksara, 2009

Zuhairini, Methodik Khsus Pendidikan Agama, Surabaya, Usaha Nasional, 1983 